\title{
The Impact of the Adoption of IFRS 16 on Accounting Conservatism in Airlines: The Case of Royal Airlines of Jordan
}

\author{
Submitted $12 / 04 / 20,1^{\text {st }}$ revision $13 / 05 / 20,2^{\text {nd }}$ revision $23 / 06 / 20$, accepted $15 / 08 / 20$
}

\author{
Ola Mohammad Khersiat ${ }^{1}$
}

\begin{abstract}
:
Purpose: This study aims to investigate the impact of adopting IFRS 16 on accounting conservatism in airlines.

Design/Methodology/Approach: The researcher has examined the impact of applying the IFRS 16 in the year of adoption 2019 and in the year before to identify the connection between the components of financial statements and accounting conservatism before and after the application of the standard, by carrying out an analytical study of the financial statements.

Findings: The study concludes that there is no statistically significant impact of the adoption of the IFRS 16 on the connection among the components of financial statements, accruals and Basu models. Additionally, there is no impact of the connection between the components of financial statements and accounting conservatism before the adoption of the standard.

Practical Implications: The study recommends the need to focus on accounting conservatism given the importance of the information presented in conservative financial statements and reports.

Originality/Value: The study analysed the impact of IFRS-16 for first time in the airline industry. The results showed that there is no impact of accounting conservatism on the items of the financial position statement whether before or after the application of IFRS16 in the airline industry.
\end{abstract}

Keywords: IFRS-16, conservatism, financial position, cash flows from operating activities (C.F.O), cash flows from financing activities (C.F.F), cash flows from investment activities (C.F.I).

JEL code: $M 41$, M42, M48.

Paper Type: Accounting study.

${ }^{1}$ University of Zarqa, Jordan, e-mail: ola_Khersiat_1978@yahoo.com; 


\section{Introduction}

Accounting standards and financial reporting are widely accepted in many countries, including Jordan. The International Financial Reporting Standard No. 16 is regarded as the latest and most important one, as a result of the joint effort between IASB and FASB. This standard has substituted the IAS 17 standard. It defines the policies and principles related to lease recognition, measurement, presentation and disclosure, which must be observed by lessors and lessees so that the information presented in the financial statements is proper and transparently representing lease contracts. The standard demands lessees to recognize most lease contracts in accordance with a model standard that affects the financial position. Moreover, recognition of lease contracts by lessors in accordance with IFRS 16 has not changed significantly compared with the requirements of IAS 17 , and the lessor shall continue classifying lease contracts as either operating or financing contracts using principles similar to those in the IAS 17 standard. Therefore, the IFRS 16 has not had an impact on lease contracts in which the company is the lessor (IFRS 16, 2019).

Companies have applied the IFRS 16 on the date of adoption of 1 January 2019 by adopting the practical transition method. Accordingly, opening balances have not been amended as well as the financial statements of the previous year. The Royal Jordanian airlines has adopted this standard on leases starting from the date of adoption. This has had an impact on total assets by $66 \%$, a value of 343.13 million Jordanian dinars, where the right of use asset for all leases has been calculated from the date of application of the standard with a value of 501.9 million Jordanian dinars. This has been met with a decrease in property and instruments calculation valued to 160 million Jordanian dinars, with a percentage of $60 \%$, because of the reclassification of owned aircrafts as per financing lease contracts of property and instrument items to use as asset items. Non-trading assets have increased because of applying the IFRS16, which resulted in the reclassification of long-term operating leases under long-term leases liabilities by 294.9 million Jordanian dinars compared to the year 2018, due to the increase in the long-term leases liabilities valued to 293.9 million Jordanian dinars.

As for trading liabilities, these have increased by 41.7 million Jordanian dinars, a percentage of $19 \%$, due to the increased liabilities under short-term leases valued to 44.0 million Jordanian dinars. The costs of revenue, as a result of applying IFRS16, led to registering consumption expenses amounting to 67351 Jordanian dinars. Depreciation expenses increased from $6 \%$ in 2018 to $15 \%$ in 2019 , and leases financing costs increased from 6605 in 2018 to 25216 in 2019, instead of operating lease expenses in the income statement. The short-term lease expenses value and the low-value leases acknowledged in the consolidated income statement for the year ended on 31 December 2019 amounted to 5415 Jordanian dinars. Regarding the impact of IFRS 16 on the cash flow statement, cash flows have been affected by operating activities due to the depreciation expense of the use of assets right, as well 
as the financing costs of lease liabilities. Cash flows have also been affected by the operating activities due to lease liabilities payments.

Accounting and financial reporting standards have addressed accounting conservatism, which is one of the basic concepts that are used in accounting practices, especially in measurement and disclosure, since it considers the minimum value of assets and the maximum value of liabilities using more assertive standards when acknowledging profits (LaFond and Roychowdhury, 2008).

Hence, this study addresses the impact of the application of IFRS 16 on accounting conservatism of airline companies and whether it is applied in measurement and disclosure.

\section{Literature Review}

Through a review of related previous studies, it is found that many have called for capitalized operating leases and their impact on the financial statements before the application of IFRS16 (Kourtis et al., 2019; Fulbier et al., 2008; Kostolansky and Stanko, 2011; Curtis et al., 2020).

Fulbier et al. (2008) analyse the proposal presented by the IASB in 2002, which proposes an accounting processing of operating leases, such as financing leases and its impact on statements and financial ratio. The study concludes that if liabilities are included in financial statements rather than disclosing them, the ratio of debt to property rights will rise by $6 \%$, trading assets to total assets will decrease by $3.9 \%$, the percentage of return on assets will decrease whereas the ratio of return on equity will rise. Kostolansky and Stanko (2011) aimed at identifying the impact of the capitalization of leases disclosed in financial statements. The study also concludes that assets and liabilities have risen with the rise in the interest rate, as well as the ratio of debt to assets, while return on assets has fallen.

Sercemeli and Ozturk (2016) aims to study the impact of applying IFRS16 on the aviation sector. It addresses the period before and after the application of the standard. The study concludes that the adoption of IFRS16 leads to inflation in assets and liabilities, and increases the ratio of debt to assets as well as the ratio of debt to property rights.

Khamees and Arabiat (2016) investigates the impact of the mandatory adoption of financial reporting standards in the companies listed in the Amman Stock Exchange between 2002-2007 on conditional conservatism. The study concludes that there is an overall decline in the adoption of IFRS and IAS over the three measures used in the study. This decline is more significant for firms that report on their intangible assets, and the impairment of goodwill. AL-Qudah and Alkubaisi (2016) investigates the factors that affect accounting conservatism, namely accounting measures and financial reporting. The study concludes that there is no statistically significant 
impact before or after the mandatory adoption of accounting standards and financial reporting as well as accounting conservatism on earnings.

Kabir and Rahman (2008) aims to apply IASB to conceptual framework in preparing financial reports in order to develop IFRS16. The study concludes that IASB has used concepts to justify IFRS16 requirements and to mitigate higher implementation costs. However, concepts have not been applied to justify IFRS16 requirements.

Parlak and Akdoğan (2019) aims to study the potential impact of adopting IFRS16 on industrial companies. The study concludes that IFRS16 affects on industrial companies that address leases significantly.

\section{Research Methodology}

In this analytical study, the researcher relies on reports and financial statements of the Royal Jordanian Airlines for 2018 and 2019 to investigate the impact of adopting the leases standard 16 on accounting conservatism. A main hypothesis, as well as six sub-hypotheses, have been formulated as follows:

HO: There is no significant statistical impact of IFRS 16 on accounting conservatism at Royal Jordanian Airlines.

The following sub-hypotheses branches off from the main one are as follows:

> H01: There is no statistically significant impact of adopting the IFRS16 on the connection between the components of the financial position statement and the accruals model at Royal Jordanian Airlines.

$>$ H02: There is no statistically significant impact of adopting the IFRS16 on the connection between the components of the financial position statement and Basu model (1997) at Royal Jordanian Airlines.

$>$ H03: There is no statistically significant impact of adopting the IFRS16 on the connection between the net income and the accruals model at the Royal Jordanian Airlines.

$>$ H04: There is no statistically significant impact of adopting the IFRS16 on the connection between the net income and Basu (1997) model at the Royal Jordanian Airlines.

$>$ H05: There is no statistically significant impact of adopting the IFRS16 on the connection between the components of cash flows statement and the accruals model at the Royal Jordanian Airlines.

$>$ H06: There is no statistically significant impact of adopting the IFRS16 on the connection between the components of the cash flows statement and the Basu (1997) model at the Royal Jordanian Airlines. 


\subsection{Hypothesis Testing}

In order to measure the impact of the standard 16 on accounting conservatism, models of accounting conservatism measures are used, namely the Accrual model and the Basu (1997) model. The research hypothesis H01 states:

H01: There is no statistically significant effect of the components of the financial position statement and the accruals model in the Royal Jordanian Airlines.

To verify this hypothesis, Pearson correlation is used to detect the strength and direction of the connection between components of the financial position statement and the accruals model in the Royal Jordanian Airlines. The multiple regression analysis is used to determine the impact of the components of the financial position statement based on the accruals model in the Royal Jordanian Airlines, as well as the coefficient of determination to measure the effect size, which represents the connection between the components of the financial position statement and the accruals model in the Royal Jordanian Airlines. Table 1 shows the Pearson correlation coefficient between the components of the financial position statement and the accruals model.

Table 1. Pearson Correlation

\begin{tabular}{|l|l|l|}
\hline Accruals model & \multicolumn{2}{l|}{ Sig. (tailed-2) } \\
\hline & .127 & .873 \\
\hline Total assets before adoption of standard & .016 & .984 \\
\hline Total liabilities before adoption of standard & .007 & .993 \\
\hline Total property rights before adoption of the standard & .640 & .360 \\
\hline Total assets after adoption of standard & .854 & .146 \\
\hline Total liabilities after adoption of standard & .169 & .831 \\
\hline Total property rights after adoption of the standard & 0.05 & 0.95 \\
\hline $\begin{array}{l}\text { Total components of the financial position statement before the } \\
\text { adoption of the standard }\end{array}$ & 0.05 & 0.45 \\
\hline $\begin{array}{l}\text { Total components of the financial position statement } \\
\text { after the adoption of the standard }\end{array}$ & 0.55 \\
\hline
\end{tabular}

Source: Own study.

Table 1 indicates, after applying Pearson correlation coefficient between the components of the financial position statement and the accruals model at the Royal Jordanian Airlines, the lack of a high correlation and a significant impact at the level of significance $(\alpha \leq 0.05)$, where the value of the correlation coefficient value of the total components of the financial position statement amounted to 0.05 with the level of significance (0.95). Also there is no high correlation and statistical significance after the adoption of the standard at the level of significance $(\alpha \leq 0.05)$, where the coefficient correlation value of the total components of the financial position statement amounted to (0.55) at a level of significance (0.45).

To determine the impact of the adoption of IFRS 16 on the connection between the components of the financial position statement and the accruals model in the Royal 
Jordanian Airlines, and to measure the effect size, which represents the connection between the components of financial position statement and the accruals model, the linear regression analysis is used, as shown in Table 2.

Table 2. Accruals model

\begin{tabular}{|l|l|l|l|}
\hline accruals model & R2 & F & Siq \\
\hline Total assets before adoption of standard & .016 & .033 & .873 \\
\hline Total liabilities before adoption of standard & .000 & .000 & .984 \\
\hline Total property rights before adoption of the standard & .000 & .000 & .993 \\
\hline Total assets after adoption of standard & 0.41 & 1.390 & .360 \\
\hline Total liabilities after adoption of standard & 0.729 & 5.388 & .146 \\
\hline Total property rights after adoption of the standard & .028 & .058 & .831 \\
\hline $\begin{array}{l}\text { Components of the financial position statement before adopting the } \\
\text { standard }\end{array}$ & 0.05 & 0.11 & 0.95 \\
\hline $\begin{array}{l}\text { Components of the financial position statement after adopting the } \\
\text { standard }\end{array}$ & 0.47 & 2.278 & 0.45 \\
\hline
\end{tabular}

Source: Own study.

Table 2 indicates that there is no statistically impact at significance level $(\alpha \leq 0.05)$ to the adoption of IFRS 16 on the connection between the components of the financial position statement and the accruals model in the Royal Jordanian Airlines, where the calculated $F$ value amounted to (2.278) at a level of significance (0.45). The value of the coefficient of determination (R2) amounted to (47\%). This means that the total components of the financial position statement after the adoption of the standard interprets (47\%) of the accruals model, the rest, amounting to $(53 \%)$ refers to other factors.

Therefore, the null hypothesis which states (H01): there is no significant impact of adopting the IFRS16 on the connection between the components of the financial position statement and the accruals model at the Royal Jordanian Airlines, is accepted. Moreover, there is no significant impact of the above mentioned before the adoption of the standard.

Table 3. Pearson correlation based on the BASU model

\begin{tabular}{|c|c|c|}
\hline \multicolumn{3}{|l|}{ Basu model } \\
\hline & Pearson & Sig. (tailed-2) \\
\hline Total assets before adoption of standard & -.654 & .346 \\
\hline Total liabilities before adoption of standard & -.734 & .266 \\
\hline Total property rights before adoption of the standard & .614 & .386 \\
\hline Total assets after adoption of standard & -.944 & .056 \\
\hline Total liabilities after adoption of standard & -.836 & .164 \\
\hline Total property rights after adoption of the standard & .230 & .770 \\
\hline $\begin{array}{l}\text { Total components of the financial position statement before the adoption } \\
\text { of the standard }\end{array}$ & -0.26 & 0.333 \\
\hline $\begin{array}{l}\text { Total components of the financial position statement after the adoption of } \\
\text { the standard }\end{array}$ & -0.52 & 0.330 \\
\hline
\end{tabular}

Source: Own study. 
Table 3 indicates, after applying Pearson correlation coefficient between the components of the financial position statement and the Basu model, the lack of a high correlation and a statistically impact at the level of significance $(\alpha \leq 0.05)$, where the value of the correlation coefficient after the application of the standard amounted to (0.52) with the level of significance (0.33). Also there is no connection between the components of the financial position statement and Basu model before the adoption of the standard.

To determine the impact of the adoption of IFRS 16 on the connection between the components of the financial position statement and the Basu model in the Royal Jordanian Airlines, and measure the effect size, which represents the connection between the components of financial position statement and the Basu model, the linear regression analysis is used (Table 4).

Table 4. BASU model

\begin{tabular}{|l|l|l|l|}
\hline BASU model & $\mathrm{R} 2$ & $\mathrm{~F}$ & $\mathrm{Siq}$ \\
\hline Total assets before adoption of standard & .428 & 1.494 & .346 \\
\hline Total liabilities before adoption of standard & .538 & 2.330 & .266 \\
\hline Total property rights before adoption of the standard & .377 & 1.211 & .386 \\
\hline Total assets after adoption of standard & .892 & 16.447 & .056 \\
\hline Total liabilities after adoption of standard & .699 & 4.644 & .164 \\
\hline Total property rights after adoption of the standard & .053 & .112 & .770 \\
\hline $\begin{array}{l}\text { Total components of the financial position statement before the } \\
\text { adoption of the standard }\end{array}$ & .448 & 1.678 & 0.333 \\
\hline $\begin{array}{l}\text { Total components of the financial position statement after the } \\
\text { adoption of the standard }\end{array}$ & .701 & 7.07 & 0.50 \\
\hline
\end{tabular}

Source: Own study.

Table 4 indicates that there is no statistically significant impact at level $(\alpha \leq 0.05)$ to the adoption of IFRS 16 on the connection between the components of the financial position statement and the Basu model in the Royal Jordanian Airlines, where the calculated $F$ value amounted to (7.07) at a level of significance (0.50). The value of the coefficient of determination (R2) amounted to (70.1\%). This means that the total components of the financial position statement after the adoption of the standard interprets $(70.1 \%)$ of the accruals model, the rest, amounting to $(29.9 \%)$ refers to other factors.

Therefore, the null hypothesis which states (H02): there is no significant impact of adopting the IFRS16 on the connection between the components of the financial position statement and the Basu model at the Royal Jordanian Airlines after the adoption of the standard, is accepted. Moreover, there is no statistically significant impact of the above mentioned before the adoption of the standard. 
The Impact of the Adoption of IFRS 16 on Accounting Conservatism in Airlines:

The Case of Royal Airlines of Jordan

Table 5. Pearson correlation based on the accruals model

\begin{tabular}{|l|l|l|}
\hline \multicolumn{2}{|l|}{ Accruals model } \\
\hline Pearson correlation & $\begin{array}{l}\text { Pearson } \\
\text { Correlation }\end{array}$ & Sig. (tailed-2) \\
\hline Net income before application of standard & .383 & .617 \\
\hline Net income after application of standard & -.742 & .258 \\
\hline
\end{tabular}

Source: Own study.

Table 5 indicates, after applying Pearson correlation coefficient between the components of the income statement and the accruals model in the Royal Jordanian Airlines, the lack of a high correlation and a statistically impact at the level of significance $(\alpha \leq 0.05)$, where the value of the correlation coefficient of the income statement average amounted to (.383) with the level of significance (.617). Also there is no high correlation and a statistically significant impact after the adoption of the standard at the level of $(\alpha \leq 0.05)$, where the value of the correlation coefficient of the income statement amounted to (-.742) at a level of significance (.258).

Table 6. Accruals model

\begin{tabular}{|l|l|l|l|}
\hline & $\mathrm{R} 2$ & $\mathrm{~F}$ & $\mathrm{Siq}$ \\
\hline Net income before application of standard & .147 & .344 & .617 \\
\hline Net income after application of standard & .550 & 2.446 & .258 \\
\hline
\end{tabular}

Source: Own study.

Table 6 indicates that there is no significant impact at the level $(\alpha \leq 0.05)$ to the adoption of IFRS 16 on the connection between the components of the income statement and the accruals model in the Royal Jordanian Airlines, where the calculated $\mathrm{F}$ value amounted to (2.446) at a level of significance (.258). The value of the coefficient of determination (R2) amounted to (55\%). This means that the components of the income statement after the adoption of the standard interprets $(55 \%)$ of the accruals model, the rest, amounting to (45\%) refers to other factors.

Therefore, the null hypothesis, which states (HO3): there is no significant impact of adopting the IFRS16 on the connection between the components of the income statement and the accruals model at the Royal Jordanian Airlines, is accepted.

Table 7. Basu model

\begin{tabular}{|l|l|l|}
\hline Pearson correlation & $\begin{array}{l}\text { Pearson } \\
\text { Correlation }\end{array}$ & Sig. (tailed-2) \\
\hline Net income before application of standard & .914 & .086 \\
\hline Net income after application of standard & .304 & .696 \\
\hline
\end{tabular}

Source: Own study.

Table 7 indicates, after applying Pearson correlation coefficient between the components of the income statement and the Basu model in the Royal Jordanian 
Airlines, the lack of a high correlation and a statistically impact at the level of significance $(\alpha \leq 0.05)$, where the value of the correlation coefficient of the income statement amounted to (.914) with the level of significance (.086). Also there is no high correlation and statistically significant impact after the adoption of the standard at the level of $(\alpha \leq 0.05)$, where the value of the correlation coefficient of the income statement amounted to (.304) at a level of (.696).

Table 8. Basu Model

\begin{tabular}{|l|l|l|l|}
\hline BASU model & R2 & F & Siq \\
\hline Net income before application of standard & .836 & 10.168 & .086 \\
\hline Net income after application of standard & .092 & .203 & .696 \\
\hline
\end{tabular}

Source: Own study.

Table 8 indicates that there is no statistically significant impact at the level $(\alpha \leq 0.05)$ to the adoption of IFRS 16 on the connection between the components of the income statement and the Basu model in the Royal Jordanian Airlines, where the calculated $\mathrm{F}$ value amounted to (.203) at a level of significance (.696). The value of the coefficient of determination (R2) amounted to (9.2\%). This means that the components of the income statement after the adoption of the standard interprets $(9.2 \%)$ of the Basu model, the rest, amounting to $(90.8 \%)$ refers to other factors.

Therefore, the null hypothesis, which states (H04): there is no significant impact of adopting the IFRS16 on the connection between the components of the income statement and the Basu model at the Royal Jordanian Airlines, is accepted. Moreover, there is no significant impact of the above mentioned before the adoption of the standard, as shown in the Table.

Table 9. Accruals model

\begin{tabular}{|l|l|l|}
\hline \multicolumn{2}{|c|}{ Pearson } & Sig. (tailed-2) \\
\hline C.F.O activities before the application of the standard & .717 & .283 \\
\hline C.F.O activities after the application of the standard & -.974 & .026 \\
\hline C.F.F activities before the application of the standard & -.321 & .679 \\
\hline C.F.F activities after the application of the standard & .183 & .817 \\
\hline C.F.I activities before the application of the standard & .745 & .255 \\
\hline C.F.I activities after the application of the standard & .359 & .641 \\
\hline $\begin{array}{l}\text { Components of the cash flows statement before the application } \\
\text { of the standard }\end{array}$ & 0.38 & 0.41 \\
\hline $\begin{array}{l}\text { Components of the cash flow statement after application of the } \\
\text { standard }\end{array}$ & -0.14 & 0.57 \\
\hline
\end{tabular}

Source: Own study.

Table 9 indicates, after applying Pearson correlation coefficient between the items of the cash flows statement and the accruals model in the Royal Jordanian Airlines, the lack of a high correlation and a statistically impact at the level of significance $(\alpha \leq$ $0.05)$, where the value of the correlation coefficient of the cash flows statement amounted to $(0.38)$ with the level of significance $(0.41)$. Also there is no high 
correlation and of statistically significant impact after the adoption of the standard at the level of $(\alpha \leq 0.05)$, where the value of the correlation coefficient of the cash flows statement amounted to (-0.14) at a level of significance (0.57). As shown in Table 9, the highest reverse value refers to cash flows from operating activities amounted to (-.974) at the level of significance (.026).

To determine the impact of the adoption of standard 16 on the connection between the items of the cash flows statement and the accruals model in the Royal Jordanian Airlines, and measure the effect size, which represents the connection between the items of cash flows statement and the accruals model, the linear regression analysis is used (Table 10).

Table 10. Linear regression

\begin{tabular}{|l|l|l|l|}
\hline accruals model & $\mathrm{R} 2$ & $\mathrm{~F}$ & $\mathrm{Siq}$ \\
\hline C.F.O activities before the application of the standard & .514 & 2.118 & .283 \\
\hline C.F.F activities before the application of the standard & .103 & .230 & .679 \\
\hline C.F.I activities before the application of the standard & 0.550 & 2.492 & .255 \\
\hline C.F.O activities after the application of the standard & .984 & 36.355 & .026 \\
\hline C.F.F activities after the application of the standard & 0.034 & 0.069 & 0.82 \\
\hline C.F.I activities after the application of the standard & 0.129 & 0.296 & 0.64 \\
\hline Total cash flows before the application of the standard & 0.39 & 1.613 & 0.41 \\
\hline Total cash flows after the application of the standard & 0.38 & 12.24 & 0.5 \\
\hline
\end{tabular}

Source: Own study.

Table 10 indicates that there is no significant impact at the level of $(\alpha \leq 0.05)$ to the adoption of standard 16 on the connection between the components of the cash flows statement and the accruals model in the Royal Jordanian Airlines, where the calculated $\mathrm{F}$ value amounted to (12.24) at level (0.5). The value of the coefficient of determination (R2) amounted to (38\%). This means that the components of the cash flows statement after the adoption of the standard interprets $(38 \%)$ of the accruals model, the rest, amounting to $(62 \%)$ refers to other factors. While there is an impact on the operating cash flows after the adoption of the standard, where the calculated $\mathrm{F}$ value amounted to (36.355) at level of significance (0.026), and it is also shown that the value of the coefficient of determination (R2) amounted to (98.4\%).

Therefore, the null hypothesis, which states $\left(\mathrm{HO}_{5}\right)$ : there is no significant impact of adopting the IFRS16 on the connection between the components of the cash flows statement and the accruals model at the Royal Jordanian Airlines, is accepted.

Moreover, there is no statistically significant impact of the connection between the items of cash flows statement and Basu model at the Royal Jordanian Airlines before the adoption of the standard.

Table 11. Accruals model

\begin{tabular}{|l|l|l|}
\hline & \multicolumn{2}{l}{ Pearson } \\
\hline C.F.O activities before the application of the standard & .441 & .559 \\
\hline C.F.O activities after the application of the standard & .689 & .311 \\
\hline
\end{tabular}




\begin{tabular}{|l|l|l|}
\hline C.F.F activities before the application of the standard & $*_{-.953}$ & .047 \\
\hline C.F.F activities after the application of the standard & -.565 & .435 \\
\hline C.F.I activities before the application of the standard & .795 & .205 \\
\hline C.F.I activities after the application of the standard & -.661 & .339 \\
\hline $\begin{array}{l}\text { Components of the cash flows statement before the application of } \\
\text { the standard }\end{array}$ & 0.094 & 0.38 \\
\hline $\begin{array}{l}\text { Components of the cash flow statement after application of the } \\
\text { standard }\end{array}$ & -0.18 & 0.36 \\
\hline
\end{tabular}

Source: Own study.

Table 11 indicates, after applying Pearson correlation coefficient between the items of the cash flows statement and the Basu model in the Royal Jordanian Airlines, the lack of a high correlation and a statistically impact at the level of significance $(\alpha \leq$ $0.05)$, where the value of the correlation coefficient of the total average of the cash flows statement items amounted to (0.094) with the level of significance (0.38). Also there is no high correlation and significant impact after the adoption of the standard at $(\alpha \leq 0.05)$, where the value of the correlation coefficient of the total average of the cash flows statement items amounted to $(-0.18)$ at a level of significance $(0.36)$.

To determine the impact of the adoption of IFRS 16 on the connection between the items of the cash flows statement and the Basu model in the Royal Jordanian Airlines, and measure the effect size, which represents the connection between the items of cash flows statement and the Basu model, the linear regression analysis is used (Table 12).

\section{Table 12. Liner regression model}

\begin{tabular}{|l|l|l|l|}
\hline BASU model & $\mathrm{R} 2$ & $\mathrm{~F}$ & $\mathrm{Siq}$ \\
\hline C.F.O activities before the application of the standard & .195 & .483 & .559 \\
\hline C.F.F activities before the application of the standard & .908 & 19.657 & .047 \\
\hline C.F.I activities before the application of the standard & 0.632 & 3.436 & 0.205 \\
\hline C.F.O activities after the application of the standard & 0.474 & 1.805 & .311 \\
\hline C.F.F activities after the application of the standard & .319 & .936 & .435 \\
\hline C.F.I activities after the application of the standard & .437 & 1.552 & .339 \\
\hline $\begin{array}{l}\text { Items of the cash flows statement before the application of } \\
\text { the standard }\end{array}$ & 0.58 & 7.86 & 0.27 \\
\hline $\begin{array}{l}\text { Items of the cash flow statement after application of the } \\
\text { standard }\end{array}$ & 0.41 & 3.45 & 0.34 \\
\hline
\end{tabular}

Source: Own study.

Table 12 indicates that there is no significant impact at the level of $(\alpha \leq 0.05)$ to the adoption of IFRS 16 on the connection between the items of the cash flows statement and the Basu model in the Royal Jordanian Airlines, where the calculated $F$ value amounted to (3.45) at level of significance (0.34). The value of the coefficient of determination (R2) amounted to (41\%). This means that the items of the cash flows statement after the adoption of the standard interprets $(41 \%)$ of the Basu model, the rest, amounting to (59\%) refers to other factors. Therefore, the null hypothesis, which states $\left(\mathrm{HO}_{6}\right)$ : there is no significant impact of adopting the IFRS16 
on the connection between the Items of the cash flows statement and the Basu model at the Royal Jordanian Airlines, is accepted.

Moreover, there is no significant impact of the mentioned above before the adoption of the standard, as shown in the above Table 12.

After testing the six sub-hypotheses, the hypothesis HO is accepted stating, "There is no significant impact of IFRS16 on accounting conservatism at the Royal Jordanian Airlines".

\section{Conclusions and Recommendations}

The study concludes, after testing the hypotheses, that there is no significant impact of IFRS16 on accounting conservatism in the Royal Jordanian Airlines. This has been proved through testing the six sub-hypotheses, which have proved that there is no connection between the items of the financial position statement and the accruals model and Basu model. There is also no impact of adopting IFRS16 on the connection between the items of the financial position statement and the accruals and Basu models. In other words, there is no impact of accounting conservatism on the items of the financial position statement whether before or after the application of IFRS 16.

Regarding the components of the cash flows statement, there is no connection between the items of the statement and the accruals and Basu models, whereas a connection is noted between C.F.O after adopting the standard and accruals model. Moreover, there is no impact of adopting IFRS16 on the items of cash flows and the accruals and Basu models, while there is impact of the adoption of IFRS16 on C.F.O activities after the application of the standard and the accruals model.

These conclusions stem from the fact that accounting and financial reporting standards see accounting conservatism as an undesirable characteristic. The results of the study conform with the studies by both Khamees and Arabiat (2016), and Alkubaisia and AL-Qudah (2016). The study recommends the need to focus on accounting conservatism when preparing financial reports and statements, due to the importance of conservative information of financial reports and statements users.

Moreover, accounting conservatism reduces problems of un-matching information. It enhances predictive capability of financial reports and statements information, accuracy of analysts ' predictions, as well as achieves applicability in the decisionmaking process.

\section{References:}

AL-Qudah, Laith, Alkubaisi, Abdulsattar. 2016. Developing Basu Model to Measure Earnings Conservatism in Jordanian Commercial Banks. Administrative Sciences, 
43(1), 511-543.

Arabiat, Omar, Khamees, Basheer, 2016. The Impact of Mandatory IFRS Adoption on Conditional Conservatism in Jordan. Dirasat, Administrative Sciences, 43(1).

Curtis, P., Hanias, M., Kourtis, E., Kourtis, M. 2020. Data Envelopment Analysis (DEA) and Financial Ratios: A Pro-Stakeholders' View of Performance Measurement for Sustainable Value Creation of the Wind Energy. International Journal of Economics and Business Administration, 8(2), 326-350. DOI: 10.35808/ijeba/465.

Deloitte (IAS Plus). 2016. IFRS 16 Leases. Available at: http://iasplus.com.

Deloitte. 2016. Leases Aguide To IFRS 16. Available at: http://deloitte.com.

Fulbier, R.U., Silva, J.L., Pferdehirt, M.H. 2008. Impact of Lease Capitalization on Financial Ratios of Listed German Companies. Schmalenbach business review, 60(1), 122-144.

Hamad, Amneh, AL-Momani Mohammad. 2018. The Effect of Accounting Conservatism in Managing the Risk of Downside of Operating Cash Flows of Companies Listed in Amman Stock Exchange: An Analytical Study. Journal of Business Administration, 81-108.

Kabir, Humayun, Rahman, Asheq. 2018. How Does the IASB Use the Conceptual Framework in Developing IFRSs? An Examination of the Development of IFRS 16 Leases, Journal of Financial Reporting, Vol. 3, No.1, 93-116.

Kostolansky, J., Stanko, B. 2011. The Joint FASB/IASB Lease Project: Discussion and Industry Implication. Journal of Business and Economics Research, 9(9), 29-36.

Kourtis, E., Kourtis, G., Curtis, P. 2019. An Integrated Financial Ratio Analysis as a Navigation Compass through the Fraudulent Reporting Conundrum: A Case Study. International Journal of Finance, Insurance and Risk Management, 9(1-2), 3-20. DOI: $10.35808 /$ ijfirm/187.

LaFond, R., Roychowdhury, S. 2008. Managerial Ownership and Accounting Conservatism. Journal of Accounting Research, 46(1), 101-135.

Ozturk, M., Sercemeli, M. 2016. Impact of New Standard IFRS 16 Leases on Statement of Financial Position and Key Ratios: A Case Study on Airplane Company in Turkey. Business and economics research journal, 7(4), 143-157.

Parlak, N., Akdoğan, H. 2019. The Comparative Review of Operating Leases According to Former IAS 17 and New IFRS 16: The Study on BIST Manufacturing Sector. Muhasebe ve Denetime Bakiş, (58), 63-82. 